\title{
Stock Market's Contribution on Economic Growth in Nepal: A Brief Note
}

\author{
Ram Khelawan Shah ${ }^{1}$
}

\begin{abstract}
This paper aims to examine the relation between stock market development and economic growth in Nepal for period of mid July 2001 to mid-July 2015 by using Karl Pearson correlation. The whole study period is divided into two parts, first stage and second stage of stock market development. The study finds that in the first stage-mid July 2001 to midJuly 2007, stock market development was not significantly associated with economic growth. In second stage-mid July 2008 to mid-July 2015 there is positive relation between stock market development and economic growth. The findings indicate that stock market has positive contribution on economic growth in Nepal.
\end{abstract}

Keywords: Market capitalization, turnover, real per capita GDP, stock market development, economic growth.

\section{Introduction}

Stock Markets are basically similar to other kinds of market. People buy and sell bargain and haggle, win and loss in this market. In stock market, people buy and sell securities, stocks and bonds which are less tangible than gold but not less valuable (Ritter \& Silber, 2012). To establish huge infrastructures and industries require long-run commitment of capital and these projects are necessary for the economic development of nation. But investors are reluctant to give up of their savings to long-run. This would require creating conducive investment atmosphere and developing efficient stock market, which help to the investors to sell their share to other investors easily. As a result, the capital is not prematurely removed (Levine \& Zerovs, 2006). However, developed countries have developed stock markets which are large in size, more liquid and less volatile. Stock market of developing countries is concentrated on few companies, it is not liquid and highly volatile.

Liquid stock markets help to buy and sell securities easily. Liquid stock markets make investment less risky and more attractive because they allow investors to buy and sell securities quickly and cheaply, and improve allocation of capital and enhance the prospective for long-run economic growth. On the contrary, liquid stock markets encourage investor myopia. Liquid stock markets may weaken investors' commitment and make easy for unsatisfied investors to sell quickly. According to this view, stock market liquidity hurt economic growth. Pardy (2012) has noted that even in less developed countries capital markets are able to mobilize domestic savings and able to allocate funds more efficiently.

Historically, the development of capital market dated back to 1936 with the flotation of share by Biratnagar Jute Mills Ltd. (NEPSE, 2009). Then government of Nepal announced industrial policy in 1974 and under this policy an institution named Securities Marketing Center (SMC) was established to deal in government securities- development bond, national saving bonds and corporate securities of few companies. In 1976 the Securities Marketing Center (SMC) was renamed by Securities Exchange Center (SEC). At that time SEC itself was doing the job of brokering, underwriting, and managing public issue because there was

\footnotetext{
${ }^{1}$ Dr. Shah is a Professor of Economics in Central Department of Economics, Tribhuvan University, Kirtipur Corresponding mail: drrkshah.nepal@gmail.com
} 
no capital market institution in Nepal other than SEC. Under the financial sector liberalization policy, Government of Nepal converted SEC into Nepal Stock Exchange Ltd. (NEPSE) in 1993 and assigned the responsibility of secondary market operation. Government of Nepal established Securities Board of Nepal (SEBON) in 1993 as a securities market regulatory authority. Within the short period of time since inception it has significantly moved ups and down. After the end of Maoist insurgency period and followed by the second Constitution Assembly (CA), NEPSE index took upward and reached upto1036.1 - the highest point in the last six year (Shrestha \& Subedi, 2014). In this way, the daily ups and down of the NEPSE index surly plays a significant role on economic activities and transactions. In this regard, an important query is raised that what is the statistical relationship between stock market development and economic growth in Nepal? This paper investigates the stock market contribution to the economic growth in Nepal. It greatly helps trading firms, researchers, academicians and mainly policy makers.

The remaining of the paper is structured as follows: Section 2 discusses relevant literature studying the share market contribution on economic growth. Section 3 discusses the data and methodology. The empirical results are discussed in section 4. Section 5 concludes the paper.

\section{Literature Review}

Academic literature on relationship between financial development and economic growth dated back to as first as the first twentieth century (Shumpeter, 2001; Mukherjee \& Souyma, 2008). But, the relationship between stock market development and economic growth has been given more attention by the academicians and researchers since last one and half decades. There is a question whether stock market in developing countries acts as a 'casino' or it has positive impact in on economic development of country. In 1995 Noble laureate Robert Lucas argued that economist frequently exaggerates the role of financial sector in economic development (Levine \& Zeroves, 2006). Singh (1997) contented that stock markets are not necessary institutions for achieving high level of economic development. Many viewed stock markets are agents that harm economic development due to their susceptibility to market failure, which is often manifest in the volatile nature of stock market in many developing countries (Levine \& Zeroves, 2006 ; Shahbaz, Ahmad \& Alile, 2008).

A number of studies indicate the importance of stock market for economic growth. Levine and Zeroves (2006) found stock market development is positively and robustly associated with long-run economic growth. They have used size, liquidity and risk diversification as measure of stock market development. Carporale, Howells and Soloman (2008) who used two indicators, the market capitalization ratio and valued traded ratio as measure of stock market development, suggested that stock market can effectively mobilize funds that have been not fully absorbed by financial intermediaries into productive investments and hence spur economic growth. Beck and Levine (2012) revealed stock markets and banks have positive influence in economic growth, and they independently assessed that stock market development has positive influence in economic growth. Beck and Levine (2012) used liquidity ratio as measure of stock market development.

Victor (2005) investigated the impact of stock market on economic growth in Ghana. Victors stated that establishment of Ghana Stock Exchange (GSE) has positive impact on economic growth in Ghana since it became operational. Oskooe (2010) stated that stock market acts as a leading indicator market development in Iran. Shahbaz et al. (2012) indicated that stock market development is an important wheel for economic growth in Pakistan. The study also argued that there is long-run relationship between stock market development and economic growth. Brasoveanue, Dragota, Catarama and Semenescu (2012), who used size and liquidity to measure stock market development, found that capital market development is positively 
correlated with economic growth in Romania, and also suggested that financial development follows economic growth. Demirguic-Kunt and Levine (2005) used market size, market liquidity, market volatility, market concentration, asset price efficiency, regulatory, institutional development, and conglomerate index. Yarty (2012) observed that macroeconomic factors such as income level, gross domestic investment, banking sector development, private capital flows, and stock market liquidity are important determinants of stock market development in emerging market countries. His result further showed that political risk, law and order and bureaucratic quality are important determinants of stock market development because they enhance the viability of external finance. Similarly, Ho (2015) mentioned that real-income level, saving rate, gross domestic investment, private capital flows, financial intermediary development and foreign portfolio investment are important and foreign portfolio investment are important determinants of stock market development especially in the industrialized and emerging market economies.

In Nepalese context, KC (2014) used the indicators size, liquidity, volatility, and concentration as used by Demirguic-Kund and Levine (2005) to measure stock market development in Nepal. However, his study only focused on the stock market development. Rana (2013) examined the causal relationship between stock market returns and some variables i.e. real GDP, interest rate and inflation. The result indicated that there is a strong unidirectional causality between real GDP and stock market returns. It concluded that real sector growth proxy by real GDP is more important in predicting stock market returns in Nepal. In another study, Shrestha and Subedi (2014) examined the determinants of Nepalese stock market performance. Their study observed performance of stock market is negative to interest rate. They argued that stock market has been found to response significantly to changes in political environment and policy of Nepal Rastra Bank. Bist (2015) mentioned that there is unidirectional causality which runs from stock market development to economic growth in Nepal. He argued that long run policy is necessary to facilitate the development of Nepalese stock market which further helps to increase overall economic growth. Since, there is huge opportunity to explore stock market in Nepalese context; it is felt necessary to study on stock market development and economic growth using more recent data in the context of Nepal.

\section{Methodology}

This paper uses time series data for the period mid July 2001 to mid July 2015. Whole study period is divided into two parts: first stage of stock market development and second stage of stock market development. First stage refers to mid July 2001 to mid July 2007 and second stage refers to mid July 2008 to mid July 2015. The data related to stock market development such as market capitalization, turnover are collected from various annual reports of Securities Board of Nepal (SEBON), and data related to economy such as per capita GDP, GDP deflator, CPI, investment, population size are collected from various publications of Economic Survey published by Government of Nepal, Quarterly Economic Bulletin published by Nepal Rastra Bank (NRB)- the Central Bank and National Account of Nepal published by Central Bureau Of Statistics (CBS).

But to examine the relationship between stock market development and economic growth, first, we need to measure stock market development. The theory does not provide unique concept or measure of stock market development (Levine \& Zeroves, 2006). This paper uses two standard measures to measure stock market development. They are market size and liquidity. Market size denotes Market Capitalization Ratio (MCR), MCR equals capitalization divided by GDP. The assumption behind this measure is that market size is positively correlated with the ability to mobilize capital and diversify to risk (Demirguic-Kunt \& Levine, 2005). Market liquidity includes total value traded ratio and turnover ratio. Total Value Traded Ratio (TVR) equals total value traded ratio and turnover ratio. Total Value 
Traded Ratio (TVR) equals total value of shares traded in stock exchange divided by GDP and Turnover Ratio (TOR) equals total value of shares traded in stock exchange divided by market capitalization. Total value traded ratio measures trading of equities transaction as a share of national output and therefore should positively reflect liquidity on an economy wide basis (Demirguic-Kunt \& Levine, 2005). High turnover ratio indicates low transaction cost and easy to buy and sell securities, and vice versa. This paper uses real per capita GDP to measure economic growth. The variables population growth rate (PGR) and total investment as percentage of GDP (INV) are also used, because they also affect the economic growth. All variables are also used, because it also affects the economic growth. All variables are in constant price of same base year $2001=100$, that is because to eliminate the inflation effect. Finally the variables used in this paper are in logarithm. The reason for taking the log is that taking logarithm of series effectively linearizes the exponential trend (if any) the time series data since the $\log$ function is inverse of an exponential function (Asteriou \& Price, 2012).

To analyze the relationship between stock market development and economic growth, this paper uses Karl Pearson correlation coefficient. The significance of the relation has been tested by using t-test and probable Error (PE).

$t=\frac{r-\rho}{S . E .(r)}$, where $\mathrm{r}=$ coefficient of correlation and S.E(r) is the standard error of $\mathrm{r}$ and

P.E. $=0.6745 \frac{\left(1-r^{2}\right)}{\sqrt{N}}$.

i) If $r<$ P.E., then correlation is not significant.

ii) If $r>$ P.E., then correlation is significant.

\section{Empirical Results}

Table-I: Stock Market Development and Economic Growth in the First Stage (Correlation Analysis)

\begin{tabular}{|c|c|c|c|c|c|c|c|}
\hline & & $\begin{array}{l}\text { Real per } \\
\text { Capita GDP }\end{array}$ & POP & INV & MCR & TVR & TOR \\
\hline \multirow{3}{*}{$\begin{array}{l}\text { Real per } \\
\text { Capita } \\
\text { GDP }\end{array}$} & Pearson Correlation & 1 & 0.186 & $-0.883(* *)$ & 0.387 & 0.007 & 0.045 \\
\hline & Sig. (2-tailed) & - & 0.690 & 0.008 & 0.391 & 0.988 & 0.923 \\
\hline & $\mathrm{N}$ & 7 & 7 & 7 & 7 & 7 & 7 \\
\hline \multirow[t]{3}{*}{ POP } & Pearson Correlation & 0.186 & 1 & -0.486 & 0.615 & 0.526 & 0.500 \\
\hline & Sig. (2-tailed) & 0.690 & - & 0.269 & 0.142 & 0.225 & 0.254 \\
\hline & $\mathrm{N}$ & 7 & 7 & 7 & 7 & 7 & 7 \\
\hline \multirow[t]{3}{*}{ INV } & Pearson Correlation & $-0.883(* *)$ & -0.486 & 1 & -0.379 & -0.129 & -0.139 \\
\hline & Sig. (2-tailed) & 0.008 & 0.269 & - & 0.402 & 0.784 & 0.466 \\
\hline & $\mathrm{N}$ & 7 & 7 & 7 & 7 & 7 & 7 \\
\hline \multirow[t]{3}{*}{ MCR } & Pearson Correlation & 0.387 & 0.615 & -0.379 & 1 & 0.687 & 0.684 \\
\hline & Sig. (2-tailed) & 0.391 & 0.142 & 0.402 & - & 0.088 & 0.090 \\
\hline & $\mathrm{N}$ & 7 & 7 & 7 & 7 & 7 & 7 \\
\hline \multirow[t]{3}{*}{ TVR } & Pearson Correlation & 0.007 & 0.526 & -0.129 & 0.687 & 1 & $\begin{array}{l}0.994(* \\
*)\end{array}$ \\
\hline & Sig. (2-tailed) & 0.988 & 0.225 & 0.784 & 0.088 & - & 0.000 \\
\hline & $\mathrm{N}$ & 7 & 7 & 7 & 7 & 7 & 7 \\
\hline \multirow[t]{3}{*}{ TOR } & Pearson Correlation & 0.045 & 0.500 & -0.139 & 0.684 & $\begin{array}{l}0.994\left(^{* *}\right. \\
)\end{array}$ & 1 \\
\hline & Sig. (2-tailed) & 0.923 & 0.254 & 0.766 & 0.090 & 0.000 & - \\
\hline & $\mathrm{N}$ & 7 & 7 & 7 & 7 & 7 & 7 \\
\hline
\end{tabular}

** Correlation is significant at the 0.01 level (Two- tailed). 
Table-1 shows the result of correlation between stock market development and economic growth in the first stage. In this stage, the correlation between MCR and real per capita GDP, TVR and per capita GDP, and TOR and real per capita GDP is positive with statistically in significant coefficient.

Table-II: Stock Market Development and Economic Growth in the Second Stage (Correlation Analysis)

\begin{tabular}{|c|c|c|c|c|c|c|c|}
\hline & & $\begin{array}{l}\text { Real Per } \\
\text { Capita GDP }\end{array}$ & POP & INV & MCR & TVR & TOR \\
\hline \multirow[t]{3}{*}{$\begin{array}{l}\text { Real per } \\
\text { Capita GDP }\end{array}$} & $\begin{array}{l}\text { Pearson } \\
\text { Correlation }\end{array}$ & 1 & 0.462 & 0.481 & $0.761(*)$ & $0.860(* *)$ & $0.847(* *)$ \\
\hline & $\begin{array}{ll}\text { Sig. } & (2- \\
\text { tailed) } & \\
\end{array}$ & - & 0.249 & 0.227 & 0.028 & 0.006 & 0.008 \\
\hline & $\mathrm{N}$ & 8 & 8 & 8 & 8 & 8 & 8 \\
\hline \multirow[t]{3}{*}{ POP } & $\begin{array}{l}\text { Pearson } \\
\text { Correlation }\end{array}$ & 0.462 & 1 & -0.224 & 0.038 & 0.161 & 0.1191 \\
\hline & $\begin{array}{ll}\text { Sig. } & (2- \\
\text { tailed) } & \\
\end{array}$ & 0.249 & - & 0.593 & 0.929 & 0.704 & 0.780 \\
\hline & $\mathrm{N}$ & 8 & 8 & 8 & 8 & 8 & 8 \\
\hline \multirow[t]{3}{*}{ INV } & $\begin{array}{l}\text { Pearson } \\
\text { Correlation }\end{array}$ & 0.481 & 0.224 & 1 & $0.866\left(^{* *}\right)$ & $0.822\left(^{*}\right)$ & $0.843(* *)$ \\
\hline & $\begin{array}{ll}\text { Sig. } & \text { (2- } \\
\text { tailed) } & \end{array}$ & 0.772 & 0.593 & - & 0.005 & 0.012 & 0.009 \\
\hline & $\mathrm{N}$ & 8 & 8 & 8 & 8 & 8 & 8 \\
\hline \multirow[t]{3}{*}{ MCR } & $\begin{array}{l}\text { Pearson } \\
\text { Correlation }\end{array}$ & $0.761(*)$ & 0.038 & $0.866(* *)$ & 1 & $0.882(* *)$ & $0.902(* *)$ \\
\hline & $\begin{array}{ll}\text { Sig. } & (2- \\
\text { tailed) } & \\
\end{array}$ & 0.028 & 0.929 & 0.005 & - & 0.004 & 0.002 \\
\hline & $\mathrm{N}$ & 8 & 8 & 8 & 8 & 8 & 8 \\
\hline \multirow[t]{3}{*}{ TVR } & $\begin{array}{l}\text { Pearson } \\
\text { Correlation }\end{array}$ & $0.860(* *)$ & 0.161 & $0.822\left(^{*}\right)$ & $0.882\left(^{* *}\right)$ & 1 & $0.998(* *)$ \\
\hline & $\begin{array}{ll}\text { Sig. } & (2- \\
\text { tailed) } & \\
\end{array}$ & 0.006 & 0.704 & 0.012 & 0.004 & - & 0.000 \\
\hline & $\mathrm{N}$ & 8 & 8 & 8 & 8 & 8 & 8 \\
\hline \multirow[t]{3}{*}{ TOR } & $\begin{array}{l}\text { Pearson } \\
\text { Correlation }\end{array}$ & $0.847\left(^{* *}\right)$ & 0.119 & $0.843(* *)$ & $0.902\left(^{* *}\right)$ & $0.998(* *)$ & 1 \\
\hline & $\begin{array}{ll}\text { Sig. } & (2- \\
\text { tailed) } & \\
\end{array}$ & 0.008 & 0.780 & 0.009 & 0.002 & 0.000 & - \\
\hline & $\mathrm{N}$ & 8 & 8 & 8 & 8 & 8 & 8 \\
\hline
\end{tabular}

* Correlation is significant at the 0.05 level (two-tailed)

** Correlation is significant at the 0.01 level (two-tailed)

Table-II shows the results of correlation between stock market development and economic growth in the second stage. In this stage correlation between MCR and real per capita GDP is positive and significant at 5 percent level. It indicates that market size is positively related with ability to mobilize the capital. Correlation between TVR and real per capita GDP is positive and significant at 1 percent level. Similarly correlation between TOR and real per capita GDP is also positive and significant at 1 percent level. It indicates that market liquidity is positively related with economic growth. The finding is consistent with Pardy (2012), Shahbaz et al. (2008), Brasoveanue et al. (2012) and Oskooe (2010). 


\section{Concluding Remarks}

This paper empirically evaluates the relationship between stock market development and economic growth in Nepal. In the first stage of stock market development, the results are to be statistically insignificant. In the second stage, both measures of stock market developmentmarket size and liquidity are positively related with economic growth. In aggregate, there is positive relationship between stock market development and economic growth in Nepal. The findings suggest that stock market activities have positive effect on economic growth of Nepal. However, the lack of information, annual data and limited observation could question the validity of the finding for a quarterly data and large number of observation.

\section{References}

Asterio, D., \& Price, S. (2012). Applied econometrics: A modern approach. New Delhi, India: Palgrave MacMillan.

Beck, T., \& Levine, R. (2012). Stock market banks and growth: Panel evidence. National Bureau of Economic Research, Working Paper No. 908.

Bist, J.P. (2015). Stock market development and economic growth in Nepal: An ARDL representation. Journal of Finance and Economics, 5(4), 164-170.

Brasoveanue, L.O., Dragota, V., Catarama, D., \& Semenescu, A. (2012). Correlation between capital market development and economic growth: The case of Romania. Journal of Applied Quantitative Method, 3(1), 120-125.

Carporale, G.M., Howells, P.G., \& Soloman, A.M. (2008). Stock market development and economic growth: A causal linkage. Journal of Economic Development, 29 (1), 33-50.

Demirguic-Kunt, A., \& Levine, R. (2005). Stock market development and financial intermediaries. Policy Research Working Paper. World Bank, No. 1462.

Ho, Sin-Yu (2015). Determinants of stock market development: A review of the literature. Studies in Economics and Finance, 34 (1), 143-164.

KC, B. (2014). Development of stock market and economic growth in Nepal. SEBON Journal, 1 (4), 25-37.

Levine, R., \& Zerovs, S. (2006). Stock market development and long-run growth. The World Bank Economic Review, 10 (2), 323-339.

MoF (Ministry of Finance) (2006). Economic Survey. Kathmandu: MoF, GoN.

MoF (Ministry of Finance) (2016). Economic Survey. Kathmandu: MoF, GoN.

Mukherjee J., \& Souyma, G.D. (2008). Does stock market cause economic growth?: A time series analysis of Indian economy. International Research Journal of Finance and Economics, 21(4), 480.

NEPSE. (2009). Various Annual Trading Report. Kathmandu: SEBON.

Oskooe, S.A.P. (2010). Emerging stock market performance and economic growth. American Journal of Applied Science, 7(2), 490.

Pardy, R., (2012). Institutional reform in emerging securities market. Policy Research Working Paper. The World Bank No. 907.

Rana, S.P. (2013). Stock market returns and micro economic movements: Is there causality? Management and Economic Review, 1 (4), 14-26.

Ritter, L.S., \& Silber, W.L. (2012). Principles of money, banking and financial market $\left(8^{\text {th }}\right.$ ed.). United States of America: Pearson Addison Wesley.

SEBON. ( n. d.). Various Issues of Annual Report. Kathmandu: SEBON.

Shahbaz, M., Ahmed, N., \& Ali, L., (2008). Stock market development and economic growth: Ardl casuality in Pakistan. International Research Journal of Finance and Ecnomics, 14(1),40-50.

Shrestha, P.K., \& Subedi, B.R. (2014). Determinants of stock market performance in Nepal. NRB Economic Review, 26 (2), 25-40. 
Shumpeter, J.A. (2001). The theory of economic development. Cambridge, Mass: Harvard University Press.

Singh, A. (1997). Financial liberalization, stock market and economic development. The Economic Journal. 107(442), 771-782.

Victor O. (2005). Does stock market matter in Ghana? A granger causality analysis. Bank of Ghana, WP/BoG-05113.

Yarty, C.A. (2012). The determinants of stock market development in emerging economies: Is South Africa different? IMF Working Paper No. 08/32 (pp.1-31). Washington, DC: The International Monetary Fund (IMF).

Note: Views and opinions expressed in this article are the personal views of author. 